University of Nebraska - Lincoln

DigitalCommons@University of Nebraska - Lincoln

August 1997

\title{
Ecological Effects of an Insect Introduced for the Biological Control of Weeds
}

Svata M. Louda

University of Nebraska - Lincoln, slouda1@unl.edu

D. Kendall

Fort Lewis College, Durango, CO

J. Connor

Rocky Mountain National Park, Estes Park, CO

D. Simberloff

University of Tennessee

Follow this and additional works at: https://digitalcommons.unl.edu/biosciecology

Part of the Ecology and Evolutionary Biology Commons

Louda, Svata M.; Kendall, D.; Connor, J.; and Simberloff, D., "Ecological Effects of an Insect Introduced for the Biological Control of Weeds" (1997). Papers in Ecology. 1.

https://digitalcommons.unl.edu/biosciecology/1

This Article is brought to you for free and open access by the Papers in the Biological Sciences at DigitalCommons@University of Nebraska - Lincoln. It has been accepted for inclusion in Papers in Ecology by an authorized administrator of DigitalCommons@University of Nebraska - Lincoln. 


\section{Ecological Effects of an Insect Introduced for the Biological Control of Weeds}

\section{S. M. Louda, ${ }^{*}$ D. Kendall, J. Connor, D. Simberloff}

Few data exist on the environmental risks of biological control. The weevil Rhinocyllus conicus Froeh., introduced to control exotic thistles, has exhibited an increase in host range as well as continuing geographic expansion. Between 1992 and 1996, the frequency of weevil damage to native thistles consistently increased, reaching 16 to 77 percent of flowerheads per plant. Weevils significantly reduced the seed production of native thistle flowerheads. The density of native tephritid flies was significantly lower at high weevil density. Such ecological effects need to be better addressed in future evaluation and regulation of potential biological control agents.

The perception of high economic, health, and environmental costs of chemical pest control has stimulated interest in biological control $(1,2)$, specifically the importation of specialized natural enemies to limit invasive coevolved pest species (3). When biocontrol is successful, pest populations are suppressed below the economic threshold by a self-sustaining interaction between the pest prey species and its introduced antagonist. Successes in the United States in-

S. M. Louda, School of Biological Sciences, University of Nebraska, Lincoln, NE 68588, USA.

D. Kendall, Fort Lewis College, Durango, CO 81301, USA.

J. Connor, Rocky Mountain National Park, Estes Park, CO 80512, USA.

D. Simberloff, Department of Ecology and Evolutionary Biology, University of Tennessee, Knoxville, TN 37996, USA.

*To whom correspondence should be addressed. E-mail: slouda@unl.edu clude biological control of insect pests, such as cottony cushion scale and red scale on citrus in southern California (4), and of weeds, such as Klamath weed (Hypericum perforatum L.) in northwestern rangelands (5) and alligatorweed (Alternanthera philoxeroides) in Florida waterways (6). However, not all biological control efforts work. Estimates of success for herbivorous insects introduced to control weeds in the United States vary, from $41 \%$ of projects with evidence of some control (2) to $20 \%$ that have exerted significant control (7). All successful programs, and many unsuccessful ones, leave nonindigenous species in the environment (8).

Biological control of invasive weeds is seen as an especially attractive option for large natural areas, such as parks, reserves, national forests, and open rangelands $(1,2$, 9). However, the use of biological control has generated controversy over the environmental risks associated with deliberate introductions of nonindigenous species. Many advocates of biological control argue that there is no evidence of significant adverse ecological effects by carefully screened insects released for weed control (10). However, the complexity of the issues (11) and the lack of data on post-release use of nontarget host plants $(8,12)$ leave the issue unresolved. Intensive study is required to identify the role of insect herbivores in the limitation of plant growth, abundance, and distribution $(13,14)$, so the lack of evidence for ecological costs may simply reflect the paucity of quantitative studies after deliberate introductions $(8,12)$.

The flowerhead weevil, Rhinocyllus conicus Froeh., was the first of four insects reported as released in North America for the biological control of Eurasian thistles of the genus Carduus L., including musk thistle (15). After extensive prerelease screenings of host preference, oviposition, growth, and fitness of this species in Italy and Canada (16), weevils from France and Italy were released in Ontario and Saskatchewan in 1968 and were immediately redistributed to Manitoba, Quebec, and British Columbia (15). Weevils from Canada were released in the United States-in Virginia (1969), Montana (1969), California (1971), and Nebraska (1972) —and then redistributed from these sites $(17,18)$. Currently, $R$. conicus is also reported from Arizona, Colorado, Idaho, Iowa, Illinois, Kansas, Kentucky, Maryland, Minnesota, Missouri, New Jersey, North Dakota, Oregon, Pennsylvania, South Dakota, Tennessee, Texas, Utah, Washington, and Wyoming (15). Redistribution continues (17). The original releases were made even after initial feeding trials indicated that the weevil's host range included the native North American genera Cirsium, Silybum, and Onopordum (16, 18). Stronger oviposition preference for Carduus, plus more successful larval development on Carduus, were expected to limit use of native North American plants by $R$. conicus (17).

We documented the continuing expansion of host range by this weevil (19); three new host associations-with Cirsium canescens Nutt., C. centaureae (Rydb.) K. Schum., and C. pulchellum (Greene) Woot. \& Standl.-were found. Infestation rates are given in Table 1 . Three of the six native thistle species in Rocky Mountain National Park-namely C. centaureae, C. tweedyi (Rydb.) Petrak, and C. undulatum (Nutt.) Spreng.- - had R. conicus developing within their flowerheads. The two lower elevation species had 43 to $70 \%$ of their flowerheads attacked (Table 1). Extensive C. undulatum infestation was also 
found in Mesa Verde National Park (38.7\%), Wind Caves National Park $(77.5 \%)$, and two Sandhills prairie preserves (Table 1 ). We also found $R$. conicus developing within flowerheads of Platte thistle, C. canescens, a characteristic species of Sandhills prairie. Studies before 1993 detected no $R$. conicus weevils on Platte thistle $(14,20)$.

The frequency of damage by $R$. conicus to flowerheads of native plants increased sharply for all study species at all sites for which we had observations in both 1992 and 1996 (Fig. 1; binomial probability $P<$ $0.008, N=7)$. The infestation levels observed were as high as or higher than those previously reported. This is true for infestation of native thistles by both native insects $(14,20-22)$ and $R$. conicus $(17,23)$, as well as for infestation of exotic thistles by exotic insects $(15,17)$.

The direct effect of $R$. conicus on seed production was severe wherever it was quantified (19). For example, in 1996 the average number of viable seeds produced by flowerheads of Platte thistle infested with weevils was $14.1 \%$ of that produced by similar heads with no insects or only native insects: 35.4 viable seeds per head without the weevil (SE 6.00, $N=40$ heads) versus 4.8 viable seeds per head with the weevil (SE 1.31, $N=181$ heads) ( $t$ test, $t_{1}=$ $7.385, P<0.001)$. Likewise, in Mesa Verde National Park in 1996, viable seed produced by wavyleaf thistle (C. undulatum) flowerheads infested with weevils averaged $28 \%$ of that produced by similar heads with no insects or only native insects.

A reduction in viable seed of the magnitude observed will reduce regeneration

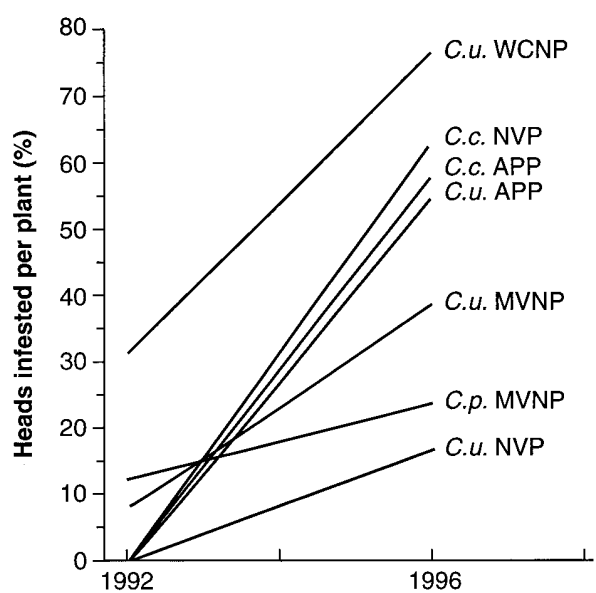

Fig. 1. Increase in the proportion of flowerheads per plant infested by $R$. conicus for $C$. undulatum (C.u.), C. canescens (C.c.), and C. pulchellum (C.p.) at Wind Cave National Park (WCNP), Niobrara Valley Preserve (NVP), Arapaho Prairie Preserve (APP), and Mesa Verde National Park (MVNP) from 1992 to 1996. from seed by these native plants. Thistles are fugitive species with large seeds that generally depend on current seed production for establishment and persistence $(20,22,24)$. For Platte thistle, field experiments have demonstrated that seed availability limited both local population density and lifetime maternal plant fitness, even before R. conicus established (14). Because Platte thistle is sparsely distributed and geographically restricted to Sandhills prairie (25), further decreases in seed, leading to decreases in local densities within the Sandhills, could threaten its global persistence. Platte thistle is also the putative progenitor (26) for Pitcher's thistle [C. pitcheri (Torr.) Torrey \& Gray], a federally listed threatened species in the Great Lakes dunes (27). The species are ecologically similar, including their susceptibility to insects (28). Thus, the impact of $R$. conicus on Platte thistle suggests that there may be comparable effects on Pitcher's thistle if the weevil establishes in the Great Lakes dune ecosystem.

Table 1. Flowerheads of native and exotic thistles with $R$. conicus damage in 1996. Results are expressed as percentage of flowerheads per plant $(X)$ with evidence of $R$. conicus. Range for all sites, except Rocky Mountain National Park, is 0 to $100 \%$.

\begin{tabular}{|c|c|c|c|c|c|}
\hline Site & Species & $\begin{array}{l}\text { Location } \\
\text { (elevation, in meters) }\end{array}$ & $\begin{array}{c}X \\
(\%)\end{array}$ & $\begin{array}{l}\text { Range } \\
(\%) \\
\text { or SE }\end{array}$ & $\begin{array}{l}\text { Plants } \\
\text { (No.) }\end{array}$ \\
\hline \multicolumn{6}{|c|}{ Native species } \\
\hline \multirow[t]{4}{*}{$\begin{array}{l}\text { Rocky Mountain } \\
\text { National Park, CO }\end{array}$} & $\begin{array}{l}\text { Cirsium centaureae } \\
\text { (elk thistle) }\end{array}$ & Beaver Meadows (2960) & 45 & $5-63$ & 24 \\
\hline & Cirsium tweedyi & $\begin{array}{l}\text { Trail Ridge Road at Ute } \\
\text { Trailhead (4150) }\end{array}$ & $<1.0$ & $0-1$ & 35 \\
\hline & Cirsium undulatum & Park Utility Area (2815) & 70 & $63-75$ & 11 \\
\hline & & $\begin{array}{l}\text { Trail Ridge Road at } \\
\text { Beaver Meadows (2960) }\end{array}$ & 43 & $17-63$ & 18 \\
\hline \multirow[t]{2}{*}{$\begin{array}{l}\text { Mesa Verde National } \\
\text { Park, CO }\end{array}$} & $\begin{array}{l}\text { Cirsium pulchellum } \\
\text { (shale thistle) }\end{array}$ & Knife Edge Trail (2406) & 24.3 & 7.71 & 21 \\
\hline & Cirsium undulatum & Sagebrush Valley (2119) & 38.7 & 10.88 & 17 \\
\hline $\begin{array}{l}\text { Wind Cave National } \\
\text { Park, SD }\end{array}$ & Cirsium undulatum & $\begin{array}{l}\text { Bison Flats Prairie } \\
\text { Restoration (1250) }\end{array}$ & 77.5 & 7.15 & 17 \\
\hline \multirow{5}{*}{$\begin{array}{l}\text { Sandhills Prairie, Nature } \\
\text { Conservancy } \\
\text { Preserves, NE }\end{array}$} & $\begin{array}{l}\text { Cirsium canescens } \\
\text { (Platte thistle) }\end{array}$ & $\begin{array}{l}\text { Arapaho Prairie Preserve } \\
\text { (1120) }\end{array}$ & 58.1 & 6.31 & 32 \\
\hline & & $\begin{array}{l}\text { Niobrara Valley Preserve } \\
\text { (795) }\end{array}$ & 63.6 & 5.48 & 42 \\
\hline & Cirsium undulatum & $\begin{array}{l}\text { Arapaho Prairie Preserve } \\
\text { (1120) }\end{array}$ & 55.3 & 11.29 & 10 \\
\hline & & $\begin{array}{l}\text { Niobrara Valley Preserve } \\
\text { (795) }\end{array}$ & 16.6 & 7.44 & 15 \\
\hline & Exotic & pecies & & & \\
\hline \multirow[t]{2}{*}{$\begin{array}{l}\text { Rocky Mountain } \\
\text { National Park, CO }\end{array}$} & $\begin{array}{l}\text { Carduus nutans } \\
\text { (musk thistle) }\end{array}$ & Horseshoe Park (2990) & 29 & $13-49$ & 30 \\
\hline & & $\begin{array}{l}\text { Hwy. 36, near Harvest } \\
\text { House (2805) }\end{array}$ & 25 & $14-35$ & 30 \\
\hline $\begin{array}{l}\text { Mesa Verde National } \\
\text { Park, CO }\end{array}$ & Carduus nutans & $\begin{array}{l}\text { Sagebrush Valley } \\
\text { (2119) }\end{array}$ & 100 & - & 14 \\
\hline $\begin{array}{l}\text { Wind Cave National } \\
\text { Park, SD }\end{array}$ & $\begin{array}{l}\text { Cirsium arvense } \\
\quad \text { (Canada thistle) }\end{array}$ & Norbeck (1311) & 77.3 & 7.15 & 22 \\
\hline $\begin{array}{l}\text { Sandhills Prairie, } \\
\text { Nature Conservancy } \\
\text { Preserves, NE }\end{array}$ & No exotic thistles & & & & \\
\hline
\end{tabular}

Native picture-winged flies (Tephritidae) often exploit the same stage and size heads as $R$. conicus $(15-17,20)$, suggesting the potential for additional, indirect effects. The recent data are consistent with this hypothesis. From 1994 to 1995-96, as the number of $R$. conicus increased significantly (21), from 0.1 per head (SE 0.04) to 3.1 (SE 0.61) ( $t$ test, $t_{1}=3.83, P<$ 0.001 ), the average number of Paracantha culta (Weid.) per Platte thistle flowerhead per plant $(N=27$ plants in 1994,46 plants in 1995) decreased significantly, from 4.1 per head per plant (SE 0.55) to 0.7 per head (SE 0.13) ( $t$ test, $t_{1}=7.553$, $P<0.001)$. Similarly, in Mesa Verde $\mathrm{Na}$ tional Park, Orellia occidentalis (Snow) disappeared from sampled flowerheads of wavyleaf thistle in 1994, at the peak of $R$. conicus density (19).

Some of these results are not surprising. Prerelease testing demonstrated that $R$. conicus is oligophagous. Cirsium species were included in its diet in Europe (15). Thus, host range expansion to North Amer- 
ican species is not completely unexpected. However, the frequency and magnitude of nontarget plant seed destruction, the time delay from introduction to host range expansion where documented (1972 to 1993 in Nebraska), the geographic extent of spread to native species, and the continuing increase in weevil feeding on native species were not predicted. The results strongly reinforce the recommendation $(11,29)$ that diet specialization is one of the crucial criteria in the selection of a biological control agent. Our study supports suggestions $(8,12)$ that further evaluation of ecological interactions be required before the deliberate release of an exotic organism. However, the outcome also reinforces suggestions that ecological consequences may be difficult to predict in advance (8).

The acceptable potential hosts for $R$. conicus, namely most thistles, often cooccur in disturbed areas and naturally dynamic habitats $(14,20,22)$. Theory suggests that the carrying capacity of an herbivore, such as $R$. conicus, in the presence of co-occurring prey species will be set by the joint availability of its resources (30), in this case flowerheads. Thus, by using flowerheads of both exotic and native species, $R$. conicus should be able to drive the native thistle population down without declining in abundance itself. A simple equilibrium that allows persistence of both a predator and a prey species, as predicted by basic biological control theory (3), is not expected when the predator has multiple prey species (30).

Biological control may be a solution to some weed problems $(1,2)$. However, our results challenge the general expectation of little environmental risk with the release of biological agents for weed control. The breadth of diet, potential host range, and ecological effects need to be investigated and then carefully weighed against the environmental costs of the pest and of alternative management options. Intensified follow-up monitoring of species that have already been released is a key step in assessing environmental costs and improving the predictability of biological control (29). The eradication of a nonindigenous species after establishment is extremely difficult at best $(7,8,11)$, so the responsibility for demonstrating that a release will have no unacceptable ecological consequences must reside with the advocates of the introduction. The potential risks to both biodiversity and ecological stability are high when a mistake occurs $(7-9,11)$. This provides strong justification for the intensive study of species already released and for an increased emphasis on rigorous, ecologically focused research on potential agents before they are released.

\section{REFERENCES AND NOTES}

1. U.S. Congress Office of Technology Assessment, Harmful Non-Indigenous Species in the United States (OTA-F-565, U.S. Government Printing Office, Washington, DC, 1993); National Research Council, Ecologically Based Pest Management: New Solutions for a New Century (National Academy Press, Washington, DC, 1995); P. B. McEvoy, Bioscience 46, 401 (1996)

2. U.S. Congress Office of Technology Assessment, Biologically Based Technologies for Pest Control (OTA-ENV-636, U.S. Government Printing Office, Washington, DC, 1995).

3. P. Debach and D. Rosen, Biological Control by Natural Enemies (Cambridge Univ. Press, Cambridge, ed. 2, 1991); P. W. Harris, Can. Entomol. 123, 827 (1992).

4. P. DeBach, Annu. Rev. Entomol. 11, 183 (1966); S. J. Walde, R. F. Luck, D. S. Yu, W. W. Murdoch, Ecology 70, 1700 (1989).

5. C. B. Huffaker and C. E. Kennett, J. Range Manage. 12, 69 (1957).

6. G. R. Buckingham, in Pest Management in the Subtropics: Biological Control-A Florida Perspective, D. Rosen, F. D. Bennett, J. L. Capinera, Eds. (Intercept, Andover, UK, 1994), pp. 413-480.

7. M. Williamson and A. Fitter, Ecology 77, 1661 (1996).

8. D. Simberloff, in Biotic Crises in Ecological and Evolutionary Time, T. H. Nitecki, Ed. (Academic Press, New York, 1981), pp. 53-81; F. G. Howarth, Annu. Rev. Entomol. 36, 485 (1991); D. Simberloff, in (31), pp. 103-117; _ and P. Stiling, Ecology 77 1965 (1996).

9. T. D. Center, J. H. Frank, F. A. Dray Jr., Fla. Entomol. 78, 45 (1995).

10. C. J. DeLoach, Nat. Areas J. 11, 129 (1991); D. Gonzalez and F. E. Gilstrap, in (31), pp. 53-70; R. I. Carruthers and J. A. Onsager, Environ. Entomol. 22, 885 (1993); D. J. Greathead, in Biological Control: Benefits and Risks, H. M. T. Hokkanen and J. M. Lynch, Eds. (Cambridge Univ. Press, Cambridge, 1995), pp. 53-63.

11. L. A. Andres, in Proc. VI Internat. Symp. Biol. Contr. Weeds, E. S. Delfosse, Ed. (Agriculture Canada, Ottawa, 1985), pp. 365-390; C. E. Turner, ibid., pp. 203-225; P. Harris, Bioscience 38, 542 (1988); R. W. Pemberton, Am. Entomol. 41, 230 (1995); Castanea 61, 313 (1996)

12. J. Diehl and P. B. McEvoy, in Proc. VII Internat Symp. Biol. Contr. Weeds, E. S. Delfosse, Ed. (Ministero dell'Agricoltura e delle Foreste and CSIRO, Rome, Italy, 1990), pp. 119-126; F. Gould, Am. Sci. 79, 496 (1991); D. Secord and P. Kareiva, Bioscience 46, 448 (1996).

13. J. L. Harper, Brookhaven Symp. Biol. 22, 48 (1969); S. M. Louda, Ecol. Monogr. 52, 25 (1982); Ecology 65, 1379 (1984); D. R. Strong, J. H. Lawton, R. Southwood, Insects on Plants: Community Patterns and Mechanisms (Harvard Univ. Press, Cambridge, MA, 1984); M. J. Crawley, Annu. Rev. Entomol. 34 531 (1989).

14. S. M. Louda, M. A. Potvin, S. K. Collinge, Am. Midl. Nat. 124, 105 (1990); S. M. Louda and M. A. Potvin, Ecology 76, 229 (1995).

15. M. H. Julien, Ed., Biological Control of Weeds: $A$ World Catalogue of Agents and Their Target Weeds (C.A.B. International, Wallingford, UK, ed. 3, 1992).

16. E. Mellini, Boll. Ist. Entomol. 18, 319 (1951); P. Harris and H. Zwolfer, Can. Entomol. 100, 295 (1968); K. E. Frick, Ed. Biological Control of Thistles in the Genus Carduus in the United States (Science and Education Administration, USDA, Stoneville, MI, 1978); H. Zwolfer and M. Preiss, Z. Angew. Entomol. 95, 113 (1983).

17. D. Schroder, Biocontrol News Inform. 1, 9 (1980); H. Zwolfer and P. Harris, Z. Angew. Entomol. 97, 36 (1984).

18. W. W. Surles, L. T. Kok, R. L. Pienkowski, Weed Sci. 22, 1 (1974); N. E. Rees, Environ. Entomol. 6, 839 (1977); M. K. McCarty and W. O. Lamp, Weed Sci. 30, 136 (1982); N. E. Rees, in Noxious Range Weeds, L. F. James et al., Eds. (Westview, Boulder, CO, 1991), pp. 264-273.

19. In Rocky Mountain National Park, all expanded this- tle flowerheads on a plant were scored by J.C. in August 1996 as no, partial, or complete seed destruction with or without $R$. conicus. In Mesa Verde and Wind Cave National Parks, flowerheads that exerted flowers were collected, measured, and dissected by D.K. in 1992 and 1994-96 for C. undulatum and in 1992 and 1996 for C. pulchellum. Head diameter and numbers of $R$. conicus oviposition scars, pupal cells, larvae, pupae, adults, other insects, and viable and damaged seeds were recorded. In The Nature Conservancy's Sandhills prairie preserves (Arapaho Prairie, Arthur County, NE, and Niobrara Valley, Brown County, NE), flowerheads of C. canescens and C. undulatum that exerted a floret were collected, measured, and dissected. Damage to the receptacle and numbers of insects, damaged and undamaged florets, and seeds were recorded.

20. W. O. Lamp and M. K. McCarty, Weed Sci. 29, 686 (1981); J. Kans. Entomol. Soc. 55, 305 (1982); Environ. Entomol. 11, 847 (1982).

21. Population growth of $R$. conicus on C. canescens was exponential from 1993 to 1996 (S. M. Louda, in preparation).

22. For example, see P. H. Zedler et al., Am. J. Bot. 70, 1516 (1983); T. J. de Jong and P. G. L. Klinkhammer, J. Ecol. 76, 366 (1988); P. G. L. Klinkhammer, T. J. de Jong, E. van der Meijden, ibid., p. 403.

23. R. D. Goeden and D. W. Ricker, Ann. Entomol. Soc. Am. 79, 945 (1986); ibid., p. 953; 80, 152 (1987); ibid., p. 161; C. E. Turner, R. W. Pemberton, S. S. Rosenthal, Environ. Entomol. 16, 111 (1987).

24. J. L. Harper, The Population Biology of Plants (Academic Press, New York, 1977); M. Fenner, Seed Ecology (Chapman Hall, London, 1985); S. M. Louda, in Ecology of Soil Seed Banks, M. A. Leck, V. T. Parker, R. L. Simpson, Eds. (Academic Press, New York, 1989), pp. 25-51.

25. Great Plains Flora Association, Flora of the Great Plains (University Press of Kansas, Lawrence, KS, 1986).

26. M. F. Johnson and H. H. Iltis, Trans. Wis. Acad. Sci. Arts Lett. 52, 255 (1963).

27. A. K. McEachern, M. L. Bowles, N. B. Pavlovic, in Restoration of Endangered Species, M. L. Bowles and C. J. Whelan, Eds. (Cambridge Univ. Press, Cambridge, 1994), pp. 194-218.

28. C. J. Keddy and P. A. Keddy, Mich. Bot. 23, 57 (1984); M. D. Loveless, thesis, University of Kansas, Lawrence (1984); L. M. Stanforth, S. M. Louda, R. L. Bevill, Ecoscience 4 (no. 1), 57 (1997).

29. H. Zwolfer and P. Harris, Annu. Rev. Entomol. 16, 159 (1971); J. R. Nechols, W. C. Kauffman, P. W. Schaefer, in (31), pp. 41-52; P. Harris and P. McEvoy, in Proc. VIII Internat. Symp. Biol. Contr. Weeds, E. S. Delfosse and R. R. Scott, Eds. (CSIRO, Melbourne, Australia, 1995), pp. 118-137.

30. R. D. Holt, Theor. Popul. Biol. 12, 197 (1977); Am. Nat. 124, 377 (1984); W. W. Murdoch, J. Chesson, P. L. Chesson, ibid. 125, 344 (1985).

31. Selection Criteria and Ecological Consequences of Importing Natural Enemies, W. C. Kauffman and J. E. Nechols, Eds. (Entomological Society of America, Lanham, MD, 1992).

32. We thank our students, S. Arevalo, R. Bevill, M. Bond, N. Brandt, J. Burger, K. Farrell, M. Gonzales, A. Hines, T. Huettner, K. Jackson, S. McLaughlin, S. McNeil, C. Murphy, M. Nichols, E. Ozolins, K. Parrish, M. Paulsen, Y. Potemkin, M. Ramspott, P. Renaud, L. Stanforth, K. Stormburg, and M. Vejvoda, for help in data collection; A. A. Steuter, M. Colyer, T. Warren, and $L$. Hays for encouragement and shared insights; C. W. O'Brien for weevil identification; the staffs of Cedar Point Biological Station, Niobrara Valley Preserve, and both national parks for logistical support; and A. Basolo, A. Joern, K. H. Keeler, S. A. Louda, J. Mulroy, D. O'Dowd, R. W. Otley, R. W. Pemberton, and D. Pilson for helpful critical input. Supported by the University of Nebraska Research Council (1984, 1990-93, 1996), NSF (grants DEB 92-21065 and DEB96-15299), and the Kathrine Ordway Stewardship Endowment (The Nature Conservancy) (S.L.) and by the Howard Hughes Biomedical Institute and the National Park Service (D.K.).

21 May 1997; accepted 18 July 1997 